\title{
Budaya Material, \\ Pakaian Dan Fashion Dalam Kehidupan Manusia
}

\author{
Oleh : Jonson Handrian Ginting
}

\begin{abstract}
A. Pendahuluan
Pakaian adalah salah satu pembahasan yang kompleks karena memiliki perkembangan yang sangat panjang. Pakaian menjadi sangat menarik untuk diperbincangkan karena memiliki sejarah yang panjang dan berliku, hampir disetiap kebudayaan memiliki corak yang berbeda dalam berpakaian serta memiliki interpretasi terhadap pakaian itu sendiri, mulai dari warna, motif, corak dan bahan yang digunakan Untuk itu menarik rasanya menulis dan mengulik sejarah pakaian dan perkembangan serta pergeserannya hingga saat ini.

Perkembangan mode busana sejalan dengan perkembangan peradaban manusia yang terkait dengan manusia sebagai makhluk yang berbudaya, yang realitanya selalu berkembang dari suatu periode ke periode berikutnya. Semakin tinggi tingkat kebudayaan manusia, maka semakin tinggi pula tingkat pemikiran manusia. Kebudayaan bersifat akumulasi, maksudnya semakin lama akan semakin bertambah kaya seperti pemikirannya, kreativitasnya, dan keterampilannya.

Sejarah perkembangan pakaian atau busana dapat dilihat dari berbagai dimensi dan cara, salah satunya adalah dengan mengulik historis evolusi manusia. Koentjaraningrat (2013) menggambarkan bagaimana perubahan manusia dari satu fase ke fase lainnya. bentuk atau objek perubahan manusia dari satu fase ke fase lain tidak hanya bertumpu pada perubahan fisik semata, tapi juga peruhaban atribut-atribut yang dipakai dan digunakan. Salah satu atribut yang juga berubah adalah pakaian.

Dari sifat dan kemampuan manusia diatasi, Prof. Drs. Harsojo (1977:116-117) mengemukakan bahwa manusia adalah homo sapiens (makhluk biologis yang dapat berpikir), sebagai homo faber (makhluk yang pandai membuat alat dan mempergunakannya), sebagai homo loquens (makhluk yang dapat berbicara dan melakukan komunikasi dengan manusia lain), sebagai homo socialis (makhluk yang dapat hidup bermasyarakat), sebagai homo economicus (makhluk yang dapat mengorganisasikan segenap usahanya untuk memenuhi kebutuhan hidupnya), sebagai homo religious (makhluk yang berpikir mengenai tempatnya di dunia dan
\end{abstract}


menyadari akan adanya kekuatan gaib yang lebih tinggi), sebagai homo delegans (makhluk yang tidak selalu mengerjakan sendiri pekerjaannya, atau mampu menyerahkan tugas kepada yang lain), sebagai homo legatus (makhluk yang mewariskan kebudayaannya kepada generasi berikutnya). Menurut Harsojo ada bagian yang sangat terkait dengan perjalanan sejarah dan perkembangan mode busana di dunia ini, seperti manusia sebagai homo sapiens akan melahirkan pemikiran manusia tentang perkembangan mode busana sejak zaman primitif sampai saat ini dan masa yang akan datang. Untuk membuat bahan busana, tentunya diperlukan alat, baik yang paling sederhana sampai dengan alat yang teknologi tinggi sesuai dengan kemajuan pemikiran manusia atau tingkat kebudayaan di mana manusia itu berkiprah, yang dalam hal ini berkaitan dengan manusia sebagai homo faber. Lebih jauh lagi bahwa manusia sebagai makhluk yang butuh berkomunikasi dan bermasyarakat, maka manusia sebagai makhluk yang berbudaya untuk kebutuhan berkomunikasi dan bermasyarakat antara lain memerlukan busana.

\section{B. Sejarah Pakaian}

Pada zaman prasejarah manusia belum mengenal busana seperti yang ada sekarang. Manusia hidup dengan cara berburu, bercocok tanam dan hidup berpindahpindah dari suatu tempat ke tempat lain dengan memanfaatkan apa yang mereka peroleh di alam sekitarnya. Ketika mereka berburu binatang liar, mereka mendapatkan dua hal yang sangat penting dalam hidupnya yaitu daging untuk dimakan dan kulit binatang untuk menutupi tubuh. Pada saat itu manusia baru berfikir untuk melindungi badan dari pengaruh alam sekitar seperti gigitan hewan seperti serangga, pengaruh udara, cuaca atau iklim dan benda-benda lain yang berbahaya.

Cara yang dilakukan manusia untuk melindungi tubuhnya pada saat itu berbeda-beda sesuai dengan alam sekitarnya. Di daerah yang berhawa dingin, manusia menutup tubuhnya dengan kulit binatang, khususnya binatang-binatang buruan yang berbulu tebal seperti domba. Kulit binatang tersebut dibersihkan terlebih dahulu dari daging dan lemak yang menempel lalu dikeringkan. Hal ini biasanya dilakukan oleh kaum wanita. Begitu juga dengan daerah yang panas, mereka memanfaatkan kulit kayu yang direndam terlebih dahulu lalu dipukul-pukul dan dikeringkan.

Penalaran paling umum dan paling logis, orang berpakaian disebabkan karena mereka mengatasi rasa dingin. Ernes Crawley (1931) mengatakan, budaya berpakaian berawal di daerah tropis belum ditemukan bukti pendukungnya. Penduduk asli Tierra del Fuego, walaupun kedinginan, disana tidak diketemukan pakaian dengan alasan 
yang masuk akal. Mereka hanya membuat perlindungan untuk melindungi diri dari angin. Orang primitif melindungi diri dari ganasnya cuaca bukan dengan cara berpakaian tetapi dengan masuk ke dalam gua atau "rumah". Hingga masa kinipun orang Eskimo melepas semua pakaiannya begitu masuk ke dalam igloo (rumah)-nya. Orang primitif juga tidak melindungi diri dari hujan dengan cara berpakaian.

Penjelasan diatas menggambarkan bahwa manusia pada saat itu mengenakan kulit hewan untuk sebuah fungsi, baik untuk menghangatkan tubuh atau menjaga tubuh dari berbagai serangan hewan lain yang mengganggu aktivitas. Orientasi pemaknaan pakaian berdasarkan fungsi ini berlanjut dan terus berkembang ke arah yang lebih kompleks nantinya.

Selain kulit hewan, ada juga yang menggunakan daun-daun kering dan rerumputan. Selain itu ada yang memakai rantai dari kerang atau biji-bijian yang disusun sedemikian rupa dan untaian gigi dan taring binatang. Untaian gigi dan taring binatang ini dipakai di bagian leher, pergelangan tangan, pergelangan kaki dan pada panggul sebagai penutup bagian-bagian tertentu pada tubuh. Pemakaian untaian gigi, taring dan tulang, selain berfungsi untuk penampilan dan keindahan juga berhubungan dengan kepercayaan atau tahayul. Menurut kepercayaan mereka, dengan memakai benda-benda tersebut dapat menunjukkan kekuatan atau keberanian dalam melindungi diri dari roh-roh jahat dan agar selalu dihormati.

Cara lain adalah dengan menoreh tubuh dan wajah dan diberi bahan pewarna yang lebih dikenal men-tattoo. Namun men-tatto menurut Roosmy M Sood dalam Dra. Arifah A Rianto, M.Pd (2003:44) bahwa semua yang dilakukan oleh masyarakat primitif belum dapat dikatakan berbusana karena seni berbusana baru muncul setelah masyarakat mengenakan penutup tubuh dari kulit binatang, kulit kayu atau bahanbahan tenunan.

Ada satu hal yang menarin bahwa "Orang perahu" dari Jepang akan melepas pakaiannya begitu turun hujan dan menyimpannya ditempat kering untuk dipakai kembali ketika hujan telah reda. Melindungi diri dari sengatan matahari mungkin merupakan bagian terpenting dari evolusi berpakaian. Membawa dedaunan untuk menutup kepala mungkin mengilhami terciptanya topi dan payung yang ada sekarang. Inipun juga masih bisa diperdebatkan. Kalau misalnya tujuan berpakaian adalah melindungi fisik, harusnya yang pertama kali dilindungi adalah kaki (sepatu) dan dengkul (decker). Moccasin (sepatu dari kulit yang lembut dipakai orang Indian Amerika Utara) dibuat lebih dulu ketimbang cawat (sekarang celana dalam). 
Mengapa? Kalau bukan untuk kesopanan, mengapa orang primitif menggantung berbagai macam barang di pinggangnya sembari menutup kemaluannya. ${ }^{1}$

Sejarah pakaian juga bisa ditelusuri dari berbagai kitab suci yang menceritakan para nabi, walaupun pendekatan ini jauh berbeda dimensi, maka wajar saja "rute" perkembangan berbeda dari pendekatan historis evolusi manusia. Pada saat nabi Adam memakan buah terlarang (kuldi), Nabi Adam dan Siti Hawa menutupi tubuh mereka dengan dedaunan yang ada di surga. Sumber lain mengatakan bahwa Nabi Idris As yang mengenalkan manusia pertama kali cara membuat pakaian. Saat itu, Nabi Idris memanfaatkan kulit pepohonan dan kulit hewan sebagai bahan pakaian, hingga kemudian sejarah mulai berkembang dan jejak sang nabi diikuti para perancang busana / pakaian dengan memanfaatkan benang yang dipintal dari kapas, bulu domba serta sutera yang kemudian dijadikan kain sebagai bahan pakaian.

Berdasarkan catatan sejarah penemuan artefak dan alat alat kuno yang ada, perkembangan kain sebagai bahan utama untuk dijadikan pakaian adalah zaman Neolithikum (Batu Baru). Pernyataan ini didasari atas ditemukannya alat tenun, misalnya gelondong benang atau alat tenun batu, membuktikan adanya proses pemintalan dan penenunan di zaman itu. Saat orang mulai tinggal di kota, tekstil makin banyak dibuat dari beragam serat. Sayangnya hanya sedikit bukti tenunan di zaman peradaban kuno yang ditemukan, misalnya dari Mesir dan Peru. Di Mesir ditemukan tenun lena yang berusia 6.000-7.000 tahun dan kain dengan pola-pola tertentu yang dibuat dengan teknik tapestri abad XV SM. Sedangkan di Peru, temuan berupa katun dan wol bulu ilama. Di tahun 5000 SM masyarakat Mesir dinilai sudah terampil menenun kain lena dari rami halus. Selain berdasarkan penemuan berupa secarik kain lena halus, pendapat itu didukung oleh temuan sejumlah mumi dari tahun 2500 SM yang terbungkus kain lena bermutu sebaik produk sekarang. ${ }^{2}$

Ternyata, pada tahun 3000 SM masyarakat lembah Sungai Indus, kini wilayah Pakistan dan India bagian barat, telah menggunakan katun kapas. Bahkan konon, di saat yang bersamaan masyarakat di Amerika telah mengolah kain sejenis itu. Sedangkan masyarakat Cina sejak sekitar tahun 2700 SM telah mengusahakan ulat sutera, selain mengembangkan alat tenun khusus untuk serat sutera. Perkiraan ini

\footnotetext{
${ }^{1}$ Wanda. 2011. sejarah manusia mengenal pakaian. http://wandaco.blogspot.co.id/2011/02/sejarahmanusia-mengenal-pakaian.html . Internet, diakses pada 28-Novermber-2015

${ }^{2}$ Zainal, Syuhada. 2014. Sejarah Tekstil Zaman Batu. Internet http://syuhadahzainal0612.blogspot.co.id/2014/06/sejarah-tekstil-di-zaman-batu.html diakses pada 2111-2015. Penjelasan mengenai perkembangan tekstil di zaman batu dihalaman selanutnya juga diambil dari sumber ini.
} 
didukung temuan potongan kecil sutera tenun berbordir menempel di patung perunggu dari Dinasti Shang (1523-1028 SM).

Di zaman prasejarah, manusia belum mengenal cara berbusana seperti yang terlihat dewasa ini. Mereka hanya berpikir bagaimana melindungi badan dari pengaruh alam sekitar, seperti gigitan serangga, pengaruh udara, cuaca atau iklim, dan benda benda lainnya yang dianggap berbahaya bagi keamanan tubuhnya, dan kelangsungan hidupnya. Manusia di zaman prasejarah yang menurut ceritanya berbulu yang kemudan menipis, sehingga merasa perlu untuk melindungi badannya. Soerjono Soekanto, SH,MA. (1975 : 94) mengatakan : "Di dalam menghadapi alam sekelilingnya seperti udara yang dingin, alam yang kejam, dan ... sebagainya, maka manusia menciptakan ...pakaian ... ." Kondisi alam sekitar di mana mereka tinggal berbedabeda, sehingga upaya yang dilakukannya berbeda-beda pula. Di daerah panas mereka menutup tubuhnya dengan kulit kayu yang mereka olah terlebih dahulu. Kulit kayu tersebut mereka rendam ter-lebih dahulu, lalu dipukul-pukul dan dikeringkan. Selain itu mereka menutup badannya dengan daun-daunan yang kering atau serat daun-daunan. Mereka yang berada di daerah yang dingin, menutup tubuhnya dengan kulit binatang hasil buruannya, terutama binatang-binatang yang berbulu tebal seperti domba, harimau, yang terlebih dahulu dibersihkan dari dagingnya dan lemaklemaknya. Selanjutnya bulu itu dikeringkan dan diperhalus.

Telah dikemukakan di atas bahwa orang menutup tubuhnya dengan kulit kayu, kulit binatang atau yang lainnya akan tergantung dari kondisi alamnya. Di daerah panas, orang membuat busana dari kulit kayu, dan di daerah dingin membuat busana dari kulit binatang. Untuk membuat busana dari kulit kayu diperlukan pengetahuan untuk mengenal jenis-jenis pohon keras tertentu yang mempunyai serat yang kuat dan panjang yang dimungkinkan dapat diolah dengan cara direndam dan dipukul-pukul, lalu dikeringkan.

Dari sinilah mulai dikenal istilah celemek panggul. Celemek panggul dipakai dengan cara mengikatkan atau membelitkan kulit kayu atau kulit binatang di sekitar pinggang dan panggul, dan dapat pula sampai menutup lutut. Celemek panggul yang terbuat dari kulit macan tutul yang biasanya hanya dipakai oleh pendeta, yang disebut lemt. Di Abesinia para pendeta sampai sekarang masih memakai celemek panggul, tetapi dari bahan beledu, sedangkan orang-orang Mesir di zaman purbakala mempergunakan kulit binatang yang dibentangkan, yang dipakai dalam bentuk busana yang khusus dipergunakan oleh pria untuk upacara. Bangsa di Amerika dahulu 
mengambil kulit pohon kayu yang masih tetap berbentuk selinder, yaitu dari pohon kayu yang dinamakan pohon kutang.

Bahan dari kulit kayu atau dari kulit binatang dan daun-daunan yang diberi lubang bagian tengahnya untuk dapat masuk bagian kepala, panjangnya bervariasi ada yang sampai di bahu, ada pula yang lebih panjang, dan bisa sampai lutut. Apabila lubang diperbesar, maka akan menutupi bagian bawah saja, yaitu mulai dari pinggang sampai panggul atau sampai ke bawah lutut. Berdasarkan bentuk poncho ini maka dapat dibedakan ponhco bahu dan poncho panggul. Bentuk poncho bahu biasa dipakai oleh suku Indian penduduk asli Amerika, Peru, Mexico, dan Tiongkok. Dipakai juga sebagai mantel oleh suku-suku Teutonic, Frank, dan Sexon di Eropa. Poncho ini ada yang dibuat sesuai aslinya dari bulu binatang.

Dari berbagai perdebatan mengenai fungsi busana diatas, muncul beberapa teori umum yang menjawab berbagai persoalan mengenai fungsi busana itu sendiri. Ada 3 teori yang melandasi tentang busana:

\section{- Teori Melindungi Diri}

Banyak alasan mengapa seseorang melindungi dirinya sendiri termasuk alasan seseorang memakai busana adalah melindungi diri dari cuaca panas dan dingin. Alasan seseorang berbusana muslim adalah melindungi diri dari para pelaku kejahatan di keramaian. Dengan berbusana muslim yang rapi dan sopan, tidak mengundang orang orang iseng di jalan untuk melakukan kejahatan. Berbeda hal nya dengan berbusana seksi, dapat mengundang orang untuk melakukan kejahatan kepadanya.

\section{- Teori Berhias}

Dalam teori berhias, busana yang dipakai harus mengutamakan estetika. Hal ini dapat membuat si pemakai busana terlihat menarik di mata orang lain dan dapat menaikkan status social seseorang. Berbusana muslim sangat dianjurkan oleh agama Islam, dengan berbusana muslim seseorang akan dipandang tinggi derajatnya di mata masyarakat.

\section{- Teori Kesopanan}


Setiap Negara memiliki nilai kesopanan yang berbeda. Negara kita mengikuti nilai kesopanan timur yang lebih mengedepankan nilai nilai Islami sehingga busana muslim adalah sebuah penerapan yang baik dan sesuai dengan teori kesopanan. ${ }^{3}$

Kemahiran manusia untuk membuat sesuatu dari alam untuk menutupi diri dari lingkungan ini tidak hanya berkembang, tapi juga Penyebaran tekstil dari timur ke barat dimulai tahun 300 SM saat bala tentara Iskandar Agung membawa pulang ke Eropa benda-benda katun dari wilayah Pakistan. Mereka lantas mengembangkan perdagangan kain secara besar-besaran dengan mengimpor pakaian wol dari Inggris, Gaul (kini Prancis), dan Spanyol, kain lena dari Mesir; Katun dari India; serta sutera dari Cina dan Persia (kini Iran). Sayangnya sedikit sekali tekstil yang bertahan dari masa Kekaisaran Romawi di Barat dan Dinasti Han (202 SM - 220) di Timur.

Industri tekstil Eropa mulai bangkit antara tahun 400-awal dan 1500-an. Inggris, Italia bagian utara, dan Flanders (kini meliputi sebagian Belgia, Prancis dan Belanda) jadi pusat produksi bagian wol. Sedangkan Italia jadi pusat produksi sutera. Dalam periode ini, tepatnya tahun 1200-an mulai dipakai roda pemintal, selain ditemukan mesin pembuka kokon sutera.

Perkembangan penting industri tekstil terjadi setelah abad pertengahan (11001500). Namun kemajuan terhebat berlangsung saat Revolusi Industri (abad XVII-awal XIX). Revolusi Industri memang berkaitan dengan revolusi industri tekstil. Ini karena membanjirnya penemuan baru di Inggris yang berakibat melonjaknya produksi benang dan kain.

Penemuan hebat itu antara lain alat pintal pertama yang mampu memintal beberapa benang sekaligus yang dikenal dengan Spinning Jenny, oleh penemu James Hargreaves pada tahun 1764. Mantan tukang cukur Richard Arkwright pada tahun 1769 mematenkan Water Frame, alat pintal bertenaga air. Tahun 1973 penemu berkebangsaan Amerika Eli Whitney mengembangkan mesin pemisah biji kapas. Alhasil, pabrik tekstil berbahan baku kapas meningkat pesat.

Hampir sepanjang sejarah, orang hanya menggunakan serat alam. Namun pada 1884 ahli Kimia Prancis Hilaire Chardonnet mengembangkan cara praktis menghasilkan serat buatan. Serat yang kini dikenal sebagai rayon pertama kali dihasilkan di AS tahun 1910 dan disebut sutera buatan. Wallace H. Corothers, ahli

\footnotetext{
${ }^{3}$ Mannequina. 2015. Busana Muslim Trendy dan Modern. Internet https://usahabusanamuslim.wordpress.com/tag/busana-muslim/diakses pada 30 November 2015. Segala informasi mengenai industri tekstil disadur dari sumber ini.
} 
Kimia Amerika, mengembangkan nilon pada pertengahan 1930-an. Sedangkan tahun 1940-1950-an mulai diperkenalkan serat buatan lain seperti polyester dan acrylic. Berbeda dengan serat alami yang pendek, serat buatan atau filamen sangat panjang dan tidak terputus. Selain itu serat buatan biasanya lebih kuat dan elastis.

Busana yang ada di masyarakat dunia dewasa ini pada prinsipnya merupakan pengembangan dari bentuk dasar busana pada peradaban Barat. Sebenarnya asal mula busana Barat pun ada sumbangan yang tumbuh dari tiga akar budaya tercakup busananya, yaitu dari Yunani kuno, Romawi, dan dunia Nasrani (Drs. Mohamad Alim Zaman, M.Pd, 2001). Busana di zaman kuno mempunyai bentuk yang dapat dibedakan menjadi tiga kelompok, yaitu : (1) rok lilit atau sarung, (2) bentuk dasar kemeja atau blus seperti tunika dan kaftan, dan (3) draperi (sepotong kain yang disusun pada tubuh, yang sering dipakai sebagai tambahan (Drs. Mohamad Alim Zaman, 2001 : 4-5). Untuk jelasnya dapat dilihat pada gambar berikut : Pada realitanya mode busana selalu berubah, berkembang, bergulir dari suatu periode ke periode berikutnya atau dari tahun ke tahun, sesuai dengan pemikiran, peradabanmanusia dan perkembangan teknologi, serta kondisi zaman pada masanya. Busanayang berasal dari Barat, busana tradisional sesuatu bangsa atau busana-busana daerahpada suatu negara, misalnya di Indonesia, Jepang, India, Malaysia, Philipina, berkembang dari bentuk dasar busana. Busana Barat tersebut pada batas-batas tertentu menyebar ke seluruh masyarakat dunia, yang tingkat penyerapannya dari setiap masyarakat berbeda-beda atau bervariasi, ada yang menyerap secara penuh, sedang, dan sedikit.

Belarih ke kerajaan-kerajaan yang ada di Indonesia, Menurut Citraninda (2012), mengacu pada busana Jawa Kuna ${ }^{4}$ pada masa kerajaan Wangsa Syeilendra, dapat dipastikan bahwa bangsa indonesia telah mengenal teknik dan keterampilan membuat busana yang cukup tua. Perkembangannya bukan hanya sampai disana, bahkan dulu masyarakat nusantara sudan mengenal semacam pembagian jenis pakaian berdasarkan status sosial pemakainya. Dengan jelas dapat kita saksikan beda pakaian raja dan serta kaum bangsawan lainnya, pakaian kaum tani-nelayan atau orang-orang kebanyakan. Berbeda pula pakaian kaum agamais dan kesatria. Setiap starus menuntut kelengkapannya sendiri dengan tata busananya sendiri. Kelengkapanatau atribut dari pakaian ini tidak bisa dipertukarkan karena adanya kesepakatan atau legitimasi akan status sosial yang disandang.

\section{Pakaian di era Modern dan Postmodern}

\footnotetext{
${ }^{4}$ Penelitian Citraninda mengenai pakaian dalam relief Candi Borobudur
} 
Abad ke 20 menjadi titik awal perubahan pakaian seiring dengan muncul dan berkembangnya teori dan paradigma modernisme. Disini pakaian tidak lagi dilihat dari sisi nilai gunanya, tapi lebih menonjolkan nilai-nila estetika yang berorientasi pada keindahan. Pergeseran ini mengubah sistem bentuk-bentuk penggunaan pakaian dari use value menjadi simbol dari nilai-nilai keindahan, pakaian tidak lagi berfungsi sebagai pelindung tubuh tapi sebagai identitas diri.

Selain hal diatas, istilah busana bergerak ke dalam pengertian luas sebagai segala sesuatu yang dipakai mulai dari kepala sampai ujung kaki yang memberi kenyamanan dan menampilkan keindahan bagi sipemakai. Secara garis besar busana meliputi (1) Busana mutlak yaitu busana yang tergolong busana pokok seperti baju, rok, kebaya, blus, bebe dan lain-lain, termasuk pakaian dalam seperti singlet, bra, celana dalam dan lain sebagainya. (2) Milineris yaitu pelengkap busana yang sifatnya melengkapi busana mutlak, serta mempunyai nilai guna disamping juga untuk keindahan seperti sepatu, tas, topi, kaus kaki, kaca mata, selendang, scraf, shawl, jam tangan dan lain-lain. (3) Aksesoris yaitu pelengkap busana yang sifatnya hanya untuk menambah keindahansipemakai seperti cincin, kalung, leontin, bross dan lain sebagainya. ${ }^{5}$

Dari uraian di atas jelaslah bahwa busana tidak hanya terbatas pada pakaian seperti rok, blus atau celana saja, tetapi merupakan kesatuan dari keseluruhan yang kita pakai mulai dari kepala sampai ke ujung kaki, baik yang sifatnya pokok maupun sebagai pelengkap yang bernilai guna atau untuk perhiasan. Pemahaman hal di atas sangat penting sekali bagi seseorang yang akan berkecimpung di bidang tata busana.

Schneider berpendapat bahwa ada dua aspek yang mempengaruhi cara berpakaian dewasa ini, estetika dan spritualitas ${ }^{6}$. Aspek estetika terkait dengan nilai-nilai keindahan serta kebebasan individu untuk menafsirkan makna keindahan, serta aspek spiritualitas terkait dengan nilai-nilai luhur dari agama dan nenek moyang dimana sebuah Objek menandakan nama, memori, sejarah dari pemilik sebelumnya. Studi kasus mengenai pakaian atau kain bagi masyarakat Samoa, tikar menandakan hubungan dengan nenek moyang, disimpan sebagai benda berharga.

\footnotetext{
${ }^{5}$ Waldi. 2010.pengerrtian busada dan macam-macamnya. http://okrek.blogspot.co.id/2010/07/pengertian-busana-dan-macam-macamnya 22.html diakses pada 29 Novermber 2015.

${ }^{6}$ Lihat Schneider, Jane. "Cloth and Clothing". Dalam Christopher Tilley. 2006. Handbook of Material Culture. London: Sage Publication. Hlm 203
} 
Dalam memenuhi kebutuhan akan busana, kadang manusia tidak semuanya membuat sendiri, tetapi dapat membeli busana yang sudah jadi, atau dipesan pada seseorang atau lembaga usaha jasa pembuatan busana, maka ini terkait dengan manusia sebagai homo delegans. Selanjutnya dari kemampuan membuat busana dapat dijadikan usaha untuk memenuhi kebutuhan hidup atau mencari penghasilan atau terkait dengan manusia sebagai homo economicus. Kebudayaan akan diwariskan kepada generasi berikutnya. Mode busana yang berkembang pada periode tertentu akan merupakan warisan budaya yang selanjutnya untuk dapat dikembangkan, dimodifikasi, diperbaharui oleh para desainer untuk menghasilkan mode yang akan menjadi trend di masyarakat. Mode fashion yang diwariskan itu terkait dengan manusia sebagai homo legatus. Jadi, dengan sifat dan kemampuan manusia tersebut salah satunya dapat mempengaruhi perkembangan mode busana di dunia ini, yang umumnya mengacu pada kebudayaan barat. Mode yang datang dari Barat ini dapat diterima dan diadaptasi sesuai kebutuhan masyarakat di negara dan daerah masingmasing. Perkembangan mode busana yang kita lihat saat ini tidak terlepas dari sejarah busana masa lalu, mulai dari peradaban kuno sampai peradaban modern saat ini yang sudah masuk pada era globalisasi. Di era globalisasi ini dengan cepat mode yang berkembang di negara lain akan masuk ke negara di mana kita berada, karena adanya peralatan teknologi yang sudah cukup canggih.

Perubahan orientasi pemaknaan atas pakaian dari nilai pakai ke nilai estetika memaksa manusia untuk membuat dan mendesain pakaian dengan berbagai bentuk yang unik serta berbeda. Hal ini juga diikuti dengan munculnya profesi baru dalam dunia kerja yaitu desainer. Para desainer berlomba-lomba untuk membuat baju yang unik dan menarik agar diminati pembeli.

Salah satu hal pokok yang mempengaruhi bentuk dan cara berpakaian adalah status dan peran, hal ini bisa kita temui di saat-saat perayaan tau ritual tertentu. misalkan pada saat ritual upacara khitan anak Sultan Yogyakarta atau yang lebih dikenal dengan upacara ngabektan atau Gres. Upacara ini dihadiri oleh para Bupati, Pangeran, Sultan dan Punakowan Kaji serta beberapa Abdi Dalem. Yang membedakan peran dan staus mereka adalah pakaian itu sendiri. Anak sultan yang akan dikhitan menggunakan Pakai puputan (tutup kepala) dihias dengan benang emas, memakai kalung bersusun tiga terbuat dari emas bertahtakan permata, bajunya berbentuk sikapan tanpa tengan berwama hitam, dihias dengan benang emas, memakai kemers disulam benang emas, pada kamers tersebut dipasang kretep bertahtakan permata, kainnya nyamping pradan dan tubuh luar di bawah perut dikenakan pakaikan lontong kanan dan kiri. Sedangkan para Pangeran berpakaian 
dinasnya, Sultan menggunakan pakaian jawa atau surjan, para Bupati menggunakan pakaian putih dan memakai keris serta Punokawan Jaji menggunakan surban putih, berbaju anteri putih dan memakain golok, serta abdi dalem menggunakan pakaian peranakan. ${ }^{7}$ Oleh karena itu, saya berpendapat pakaian adalah salah satu penanda yang paling jelas dari sekian banyak penanda penampilan luar, dengan apa orang membedakan diri mereka dari orang lain dan pada gilirannya diidentifikasi sebagai sebuah kelompok tertentu.

Pakaian bahkan dapat membuat orang dibunuh. Hal ini terjadi apabila seseorang misplace dan displace dalam memilih pakaian. Kisah ini terjadi pada Dr. C.B. Robinson, seorang ahli botani Inggris yang ditugaskan di Manila, ketika ia mengunjungi Ambon pada Desember 1913. Residen Belanda menghubungkan pembunuhan tersebut dengan penampilan "fantastis" Dr. Robson yang sangat berbeda dengan beberapa bangsa Eropa yang pernah berjumpa dengan suku Buton Muslim yang telah membunuhnya. Karena secara umum mereka telah menyimpan ketakutan terhadap bangsa Eropa maka kelika melihat Dr. Robinson yang malang berpakaian warna khaki gelap dengan topi beludru yang aneh dan semacam pisau berburu di pinggangnya". 8

Berdasarkan pada kisah diatas, saya berpendapat bahwa pakaian merupakan ekspresi tentang cara hidup. Pakaian dapat mencerminkan perbedaan status dan pandangan politik atau religius. Dengan demikian, cara kita memilih pakaian dapat berfungsi sebagai suatu pernyataan, sebagai sarana yang menunjukkan bakwa kita berasal dari kelompok tertentu yang berbagi sekumpulan nilai-nilai ideal tertentu. pandangan-pandangan yang berbeda tentang bagaimana seharusnya masyarakat diatur tersebar secara meluas pada beragam pendapat tentang bentuk pakaian yang benar. Pembahasan-pembahasan seperti ini sering berkonsentrasi pada pakaian teftentu. Bagi perempuan Muslim, mungkin kerudung atau jilbab yang menjadi fokus perdebatan, dengan mengubah kerudung atau jilbab menjadi simbol tentang suatu cara berpakaian yang khas.

Gaya berpakaian yang dapat dipilih oleh masyarakat memang sangat beragam bentuk dan macamnya. Pada saat ini warga negara di Indonesia dapat memilih

\footnotetext{
7 Lihat Jandra, Drs. Mifedwil. 1990. "Perangkat Atau Alat-Alat Dan Pakaian Serta Makna Simbolis Upacara Keagamaan Di Lingkungan Keraton Yogyakarta". Proyek Invertarisasi Dan Pembinaan NilaiNilai Budaya DIY, Direktorat Sejarah Dan Nilai Tradisional, Direktorat Jendral Kebudayaan, Departemen Pendidikan Dan Kebudayaan. HIm 75-76.

8 Lihat Dijk, Kess Van. "Sarung, Jubah Dan Celana: Penampilan Sebagai Sarana Pembedaan Dan Diskriminasi". Dalam Nordholt, Heng Schulte. 1997. "Outweard Appearances: Trend, Identitas Dan Kepentingan". Yogyakarya: LkiS. HIm 57
} 
pakaian daerah untuk upacara-upacara pernikahan. Pada pertemuan-pertemuan keagamaan mereka memakai pakaian yang menonjolkan latar belakang kemuslimannya dan Memakai kemeja batik modern pada acara resepsi, mengenakan setelan gaya barat untuk menjalankan negosiasi-negoisasi bisnis yang penting, berangkat kerja memakai kemeja polos, dan lain-lain.

Pengaturan cara berpakaian pada intinya adalah pengaturan tubuh (Jeacle, 2012: 84). Proyek pengaturan tubuh tidak lagi diperuntukkan bagi para kaum elit tapi juga bagi masyarakat ramai. Dengan demikian, mendandani dan membentuk tubuh melalui pakaian adalah bagian penting dari penemian atau pembentukan objek dan subjek pengetahuan dan pengalaman baru. Contoh yang menarik dari kasus ini adalah pakaian batik di Kraton Yogyakarta. Ada beberapa motif-motif batik yang hanya boleh dipakai oleh kalangan raja dan bangsawan dan ada pula yang motif-motif yang biasa dipakai atau dimiliki oleh masyarakat ramai. Sekarang, ketika pusat-pusat kekuatan dan kekuasaan tradisional Keraton melemah dan kekuasaan negara nasional (Indonesia) semakin kuat, motif-motif yang private atau yang dianggap sakral sudah bisa dipakai oleh orang di luar keluarga Sultan dan bangsawan sepanjang orang tersebut memiliki sejumlah uang untuk membeli. Bahkan, motif-motif batik yang sakral itu tidak lagi diproduksi dengan cara lama dimana memiliki nilai kerja banyak tapi diproduksi secara masal dan masif dengan alat mesin agar biaya yang dikeluarkan lebih terjangkau.

Penjelasan diatas menyeret kita untuk sepakat bahwa penampilan itu sangat penting, terutama tampilan luar karena dari situ kita dapat menentukan berapa banyak nilai plus yang bisa diberikan kepada orang yang sedang kita nilai tersebut. Penilaiannya pun sangat subyektif karena didasari oleh "selera pasar" yang cenderung global. Misalnya saja cara berpakaian. Kebanyakan dari kita cenderung lebih suka menilai seseorang dari cara berpakaiannya -Yang pastinya sudah menjadi sesuatu yang klise, "orang baik-baik" berpakaian rapih dan "yang bukan orang baik-baik" berpakaian ala kadarnya (atau terkesan seenaknya). Ini semua menjadi sebuah aturan normatif yang baku sehingga banyak orang cenderung memilih menggunakan pakaian berdasarkan penilaian lingkungan sekitarnya, dimana ukuran pantas atau tidaknya penampilan seseorang ditentukan oleh orang lain yang berada di dalam lingkaran sosialnya.

Cara berpakaian seseorang dahulu ditentukan nilai dan normanya secara bersama, layak dan tidak layak merupakan hal yang dilegitimasi bersama oleh masyarakat sehingga orang atau masyarakat akan berpakaian sesuai dengan nilai dan norma yang dibangun dalam masyarakat. Kini, layak dan tidak nyaman itu digeser oleh 
sebuah rasa private yang disebut dengan istilah rasa nyaman. Artinya, orang-orang tidak lagi berpakaian sesuai yang diinginkan masyarakat tapi sesuai dengan hak nyaman individu karena setiap individu berhak atas konsumsi dan fashion-nya sendiri. Bentuk-bentuk pakaian yang sebulumnya ditetapkan secara objektif kini berubah ke ranah yang memiliki subjektivitas yang sangat tinggi karena menyangkut individu tersebut. Oleh karena itu menginsumsi pakaian atau fashion berarti sekaligus sebagai bentuk pengaturan tubuh dan cara merasakan dunia material dan sosial pemakaianya. Praktik konsumsi ini juga ikut membentuk cara manusia merasakan dunia sosial dan dunia material hingga memunculkan tile subjektivitas tertentu dalam konteks kebudayaan dan hidup sehari-hari.

mengonsumsi pakaian dengan mengikuti tren biasanya membentuk perasaan seseorang eksis: hadir, ada dan diakui. Diakui sebagai individu yang unik lewat pengakuan atas sekelompok orang yang memakai pakaian yang sama. Dengan demikian, tren fashion menciptakan paradoks antara perbedaan dan kesamaan sehingga secara indrawi orang sulit untuk melihat perbedaan latar beakang identitas seseorang melalui pakaian yang dikenakan.

Lebih jauh lagi, tren pakaian sangat erat kaitannya dengan merek. Merek yang sebenarnya bersifat immaterial, dihubungkan dengan pakaian yang bersifat material, lewat berbagai promosi di media sehingga menjadi tren. Keinginan untuk menjadi bagian dari tren tersebut memunculkan produk "kw" atau tiruan. Melalui pengalaman menyentuh, memakai dan melihat sosok yang mengenakan pakaian, perbedaan identitas dan keunikan bertransformasi menjadi perbedaan antara "asli" dan "palsu". Merek dalam hal ini menjadi persilangan antara indrawi (sensuous) dengan pemahaman; klasifikasi dari elemen-elemen yangg terkomoditisasi dan kualitas yang bersifat immaterial (reputasi, citra, afeksi dan karakter) yang membuat objek material bisa dirasakan oleh pemiliknya secara unik dan diaktualisasikan di dunia.

Selain merek, Salah satu hal penting dan cukup mendapatkan perhatian adalah berbagai material goods yang memiliki nilai yang tinggi. Nilai ini dibangun atas kehidupan sosial benda tersebut dimasa objek tersebut masih dipergunakan. Nilai tersebut melekat pada nilai authentic benda tersebut (Gell,1986:111) ${ }^{9}$. Berbagai kalangan dengan rela saja mengeluarkan uang berjuta-juta rupiah atau dolar apabila benda tersebut adalah pakaian dari idolanya atau idola dunia. Hal ini bisa menjelaskan mengapa baju-baju pemain bola legendaris ingin dimiliki oleh banyak orang.

\footnotetext{
${ }^{9}$ Lihat Gell, Alfred. "Newcomers To The World Of Good: The Comsumtion Among Muria Gonds". Dalam Appadurai, Arjun. 1986. "The Social Life Of Things". London: Cambridge University Press.
} 
Dalam hal ini, Miller (1987: 133) mengatakan bahwa sebenarnya pengonsumsian barang secara berlebih adalah sebuah kesia-siaan manusia sebagai subjek diluar dari kebutuhan ekonomi primernya. Disini saya bisa menangkap apa yang dimaksud dengan kebutuhan dan keinginan, ketika barang tidak lagi dilihat dibutuhkan dari segi fungsi, maka sebenarnya yang kita beli atau konsumsi adalah sebuah kesia-siaan. Namun pada hakikatnya, kesia-siaan itu hanyalah sebuah kekurangan atau pemborosan. bagi konsumtor, secara tidak langsung ia telah mendapatkan apa yang dia inginkan dan mempengaruhi psikologis.

Pada era postmodernisme, dimana segala batasan-batasan umum dari berpakaian dileburkan dan direkonstruksi secara suka-suka, perkembangan fashion bahkan bisa bergerak ke arah yang extreme. di Jepang, ada sekelompok orang yang melabeli diri mereka sebagai Gangoru atau gongoru, mereka banyak terdapat di shibuya. Komunitas ini bergaya seperti orang Afro-America, dengan kulit yang sangat gelap dan rambung yang di-bleancing, mereka selalu tampil nyentrik dan ceria seceria warna warni elektrik dan perhiasan berwarna emas yang dikenakannya. Mereka benar-benar ingin melawan konsep "wanita cantik" yang ada di masyarakatnya. ${ }^{10}$

\section{Kesimpulan}

Pakaian merupakan kajian yang sangat kompleks, mengingat sejarah manusia itu sendiri tidak bisa dilepaskan dari sejarah pakaian. Dimensi ruang dan waktu pakaian berjalan dari fungsi sampai nilai dan estetika. Pakaian bisa menjadi identitas sekelompok orang bahkan bisa menunjukkan kelas sosial.

Bentuk dan fungsi pakaian dapat dilacak perubahannya dari berbagai era dan masih bisa ditemui sampai sekarang. Di masa fungsi bukan lagi tujuan utama dalam berpakaian, manusia menjadikan pakaian sebagai bentuk eksistensi diri dan identitas sosial. Pakaian menjadi bagian paling luar manusia yang mampu menjelaskan banyak hal. Model dan bentuk menjadi hak kebebasan individu untuk berekspres mulai dari bentuk yang sangat sederhana sampai bentuk ekstrem.

Perkembangan fashion memang tidak akan ada habisnya, sampai saat makalah ini dibuat, perkambangan fashion masih terus berkembang sampai ke batasbatas yang tidak bisa diraba dan dijelaskan secara spesifik. Hal ini terkait dengan

\footnotetext{
${ }^{10}$ Lihat Macias, Patrick. Izumi, Evers. 2007. Japanese Schoolgirl inferno: tokyo teen fashion subculture handbook. California: chronicle book. dalam Nurhayati, Hesti. 2012. Hara-Shibu-Bara: Tokyo Street Fashion Paradise. Jakarya: Grasindo
} 
segala macam bentuk ekspresi dari masyarakat yang menggunakan atau bentuk fashion tersebut. 


\section{REVERENSI}

Appadurai, Arjun. 1986. "The Social Life Of Things". London: Cambridge University Press.

Arifah A. Riyanto. 2003. "Teori Busana". Bandung : Yapemdo.

Barthes, Roland. 1983. "The Fashion System”. New York: Hill And Wang.

Crawley, Ernes. 1931. "Dress, Drinks, \& Drums-Further Studies of Savages \& Sex". London: Methuen

Dalam Christopher Tilley. 2006. Handbook of Material Culture. London: Sage Publication

Ingrid Jeacle, Chris Carter, (2012) "Fashioning The Popular Masses: Accounting As Mediator Between Creativity And Control", Accounting, Auditing \& Accountability Journal, Vol. 25 Iss: 4

Jandra, Drs. Mifedwil. 1990. "Perangkat Atau Alat-Alat Dan Pakaian Serta Makna Simbolis Upacara Keagamaan Di Lingkungan Keraton Yogyakarta". Proyek Invertarisasi Dan Pembinaan Nilai-Nilai Budaya DIY, Direktorat Sejarah Dan Nilai Tradisional, Direktorat Jendral Kebudayaan, Departemen Pendidikan Dan Kebudayaan.

Koentjaraningrat. 2013. "Pengantar IImu Antropologi". Jakarta: Rineka Cipta.

Macias, Patrick. Izumi, Evers. 2007. "Japanese Schoolgirl Inferno: Tokyo Teen Fashion Subculture Handbook. California: Chronicle Book". Dalam Nurhayati, Hesti. 2012. "Hara-Shibu-Bara: Tokyo Street Fashion Paradise". Jakarya: Grasindo

Miller, Daniel. 1987. “Material Culture And Mass Consumption”. London: T.J. Press

Mohammad Alim Zaman. (2001). "Kostum Barat Dari Masa Ke Masa”. Jakarta : Meutia Cipta Sarana.

Noerhadi, Indra Citraninda. 2012." Busana Jawa Kuna”. Depok: Komunitas Bambu

Nordholt, Heng Schulte. 1997. "Outweard Appearances: Trend, Identitas Dan Kepentingan". Yogyakarya: LkiS

Prof. Hardjoso. 1984. “Pengantar Antropologi”. Jakarta: Binacipta

Soekanto, Soerjono. 1975. "Bibliografi Humuk Adat Indonesia: Akhir Abad XIX". Bandung: Alumni 


\section{Sumber Internet:}

Zainal, Syuhada. 2014. "Sejarah Tekstil Zaman Batu". Internet Http://Syuhadahzainal0612.Blogspot.Co.Id/2014/06/Sejarah-Tekstil-Di-ZamanBatu. Html Diakses Pada 21-11-2015.

Waldi. 2010."Pengertian Busada Dan Macam-Macamnya". Internet Http://Okrek.Blogspot.Co.Id/2010/07/Pengertian-Busana-Dan-MacamMacamnya 22.Html Diakses Pada 29 Novermber 2015.

Wanda. 2011. "Sejarah Manusia Mengenal Pakaian". Internet Http://Wandaco.Blogspot.Co.Id/2011/02/Sejarah-Manusia-Mengenal-Pakaian.Html . Internet, Diakses Pada 28-Novermber-2015

Palupi, Indrayani Nur. 2012. "Desain Busana Dan Teori”. Internet Http://Www.Desainbusana.Com/2012/06/Desain-Busana-Dan-Teori.Html Diakses Pada 28-Novermber-2015

Mannequina. 2015. "Busana Muslim Trendy Dan Modern". Internet

Https://Usahabusanamuslim.Wordpress.Com/Tag/Busana-Muslim/ Diakses Pada 30 November 2015 